Article

\title{
Stimulating Non-Energy Exports in Trinidad and Tobago: Evidence from a Small Petroleum-Exporting Economy Experiencing the Dutch Disease
}

\author{
Roger Hosein ${ }^{1, *(\mathbb{D}}$, Leera Boodram ${ }^{1} \mathbb{D}$ and George Saridakis ${ }^{2}$ \\ 1 Department of Economics, The University of the West Indies, St. Augustine, Trinidad and Tobago; \\ leeraboodram02@gmail.com \\ 2 Business School, The University of Kent, Canterbury CT2 7NZ, UK; G.Saridakis@kent.ac.uk \\ * Correspondence: Roger.Hosein@sta.uwi.edu
}

check for

updates

Citation: Hosein, Roger, Leera

Boodram, and George Saridakis. 2022. Stimulating Non-Energy Exports in Trinidad and Tobago: Evidence from a Small Petroleum-Exporting Economy Experiencing the Dutch Disease. Journal of Risk and Financial

Management 15: 36. https://doi.org/ 10.3390/jrfm15010036

Academic Editor:

Mihaela Simionescu

Received: 29 November 2021

Accepted: 20 December 2021

Published: 13 January 2022

Publisher's Note: MDPI stays neutral with regard to jurisdictional claims in published maps and institutional affiliations.

Copyright: (C) 2022 by the authors. Licensee MDPI, Basel, Switzerland. This article is an open access article distributed under the terms and conditions of the Creative Commons Attribution (CC BY) license (https:// creativecommons.org/licenses/by/ $4.0 /)$

\begin{abstract}
The motivation for this study hinges around the fact that Trinidad and Tobago (T\&T) is suffering from the Dutch disease which inadvertently hinders the growth of non-energy exports. This paper examines measures that can be adopted for a small petroleum-exporting economy to dampen the effect of Dutch disease by promoting non-energy trade. This paper is novel and contributes to the literature in using panel data for the T\&T case, as it investigates the effect of a devaluation of the TT dollar in order to stimulate non-energy exports (a combination of agriculture and manufacturing trade). Note that previous studies would have examined the Marshall-Lerner condition on the aggregate trade balance which is heavily influenced by energy revenues. The panel autoregressive distributed lag (ARDL) method is used for ten of T\&T's main trading partners for the period 1991 to 2019 to establish findings. The results show that the Marshall-Lerner condition does not hold for aggregate trade in the long run, as expected. However, when non-energy trade is isolated, it is found that a devaluation of the TT dollar does have a positive impact on non-energy trade and the Marshall-Lerner condition holds. Other measures are also recommended to stimulate non-energy exports in the long run.
\end{abstract}

Keywords: Trinidad and Tobago; Marshall-Lerner condition; non-energy trade

\section{Introduction}

Trinidad and Tobago (T\&T) is at the tail end of a natural gas boom where the country has seen its main source of revenue inflows diminish from the energy sector as a result of the Dutch disease which hinders the growth of non-energy exports via direct and indirect deindustrialization which serves as a motivation to undertake this study. This paper examines measures that can be adopted for a small petroleum-exporting economy to dampen the effect of Dutch disease by promoting non-energy trade. Policy makers can firstly evaluate the feasibility of a devaluation of the T\&T dollar (TT dollar hereafter) in order to stimulate non-energy exports. Usui (1997), for example, states that a devaluation of the Indonesian currency in 1978 was instrumental in increasing manufacturing production, by reversing the "appreciated" real exchange rate, as without this, the appreciation of the real exchange rate due to an oil boom would have seriously limited the expansion of the manufacturing sector. Usui (1997) also notes that although there was inflation, the devaluation of the rupiah was effective in avoiding the contraction of the tradable sector as a result of Dutch disease.

There have been calls for and against the devaluation of the country's currency in an attempt to stimulate T\&T's exports (Regis 2020). In 2018, the IMF (International Monetary Fund 2018) stated that the exchange rate could assist as an automatic stabilizer and manage the transition to a more balanced foreign exchange market. Furthermore, the TT dollar is substantially overvalued and there is a persistent shortage of foreign exchange. The 
International Monetary International Monetary Fund (2016) also stated that by the end of 2015, the exchange rate was overvalued by 30 percent using a Consumer Price Index (CPI) approach, 21.3 percent using Current Account (CA) regression estimates and approximately 50 percent using the Real Effective Exchange Rate (REER) regression. In order to assess whether a devaluation of T\&T's currency would be effective, the Marshall-Lerner condition must be satisfied. Previous studies from Straughn (2004) and Wilson and McLean (2014) note that the Marshall-Lerner condition does not hold for T\&T and a devaluation of the TT dollar would not be able to stimulate exports in either the short run or the long run.

This paper reevaluates existing literature on devaluing the TT dollar by examining the Marshall-Lerner condition on the aggregate trade balance from 1991 to 2019. It goes a step further and examines the effect of a devaluation of the currency on the non-energy trade balance (a combination of agriculture and manufacturing trade) using a panel autoregressive distributed lag (ARDL) model with supporting robustness tests. Previous studies would have examined the Marshall-Lerner condition based on the aggregate trade balance which is heavily influenced by energy revenues for T\&T (see Boyd and Smith 2005; Straughn 2004; Wilson and McLean 2014). The main contribution of this paper was to isolate the effects of energy revenue for a petroleum-exporting economy in order to determine whether a devaluation of the currency would stimulate non-energy exports. It is also a novel paper with regards to T\&T and can also be applicable to any resource-based economy that is experiencing Dutch disease. Other measures are also suggested to complement implementing a devaluation to have a robust measure of stimulating non-energy trade.

Our findings reveal that a devaluation of the TT dollar does not have a significant impact in the short run nor the long run in stimulating aggregate trade, as expected. Previous studies from Boyd and Smith (2005), Straughn (2004) and Wilson and McLean (2014) stated that the Marshall-Lerner condition did not hold for T\&T and a devaluation was not feasible in the short run nor the long run. This study is consistent with the findings that the Marshall-Lerner condition does not hold for aggregate trade in the long run. This paper further adds to the literature for the T\&T case, by investigating whether the Marshall-Lerner condition would affect non-energy trade. Note that a constraint on this study is that the quality and quantity of services data required to execute a panel study for comparison was not available to determine whether the Marshall-Lerner condition holds for services. However, given that the country is affected by the Dutch disease, this leads to the deindustrialization of the non-booming sectors (agriculture and manufacturing) via direct and indirect deindustrialization and this result in the unsustainable expansion of the services sector. This in turn leads to the Baumol Cost Disease. Hence, this paper focuses on promoting non-energy trade as a means to dampen the Dutch disease and promote sustainable means for trade.

The results indicate that a devaluation of the TT dollar would assist non-energy trade in the long run and the Marshall-Lerner condition holds for non-energy trade after isolating agriculture and manufacturing trade. The paper argues that other measures such as improving the ease of doing business and assessing current and potential markets provide an avenue for policy makers to stimulate non-energy exports in the long run. The paper is also novel in combining a trade competitive analysis of nations (TradeCAN) and revealed comparative advantage (RCA) analysis to help identify non-energy export areas to boost exports in these sectors in an attempt to curb the effects of Dutch disease. Additionally, policy measures can be considered to improve T\&T's ease of doing business rankings which have been deteriorating and also to ensure smoother production flows in the non-energy sector. Specifically, this paper provides answers to the following key questions:

(i) Does devaluing the TT dollar have a significant impact on aggregate trade?

(ii) Is devaluation a feasible alternative in promoting non-energy exports?

(iii) Is import substitution feasible in promoting the growth of non-energy trade?

(iv) What other measures can be adopted in tandem with a devaluation of the currency if feasible, to promote non-energy exports? 
The paper progresses as follows: Section 2 entails the literature review on the MarshallLerner condition; Section 3 presents the data; Section 4 entails the empirical model, followed by a discussion of findings in Section 5. The paper finishes with a conclusion, which contains relevant policy recommendations to consider simultaneously when considering a devaluation of the TT dollar.

\section{Literature Review: Examining the Marshall-Lerner Condition in Various Countries}

The Marshall-Lerner condition also known as the Marshall-Lerner-Robinson condition was derived independently by Alfred Marshall, Abba Lerner and Joan Robinson. The Marshall-Lerner condition shows that a devaluation or depreciation improves a country's trade balance if the sum of the absolute values of a country's import and export price elasticities are greater than one. The Marshall-Lerner condition has widely been investigated for a number of countries and also particular industries. However, the results are mixed where the Marshall-Lerner condition holds for a number of countries and industries (see Boyd et al. 2001; Hsing 2010; Eita 2013; Turkay 2014; Caporale et al. 2015; Cambazoglu and Gunes 2016; Arruda et al. 2019) whilst the condition does not hold for others (Whitehall 1986; Richards 1996; Boyd and Smith 2005; Bahmani et al. 2013; Straughn 2004; Wilson and McLean 2014; Shahzad et al. 2017; Adhikari 2018; Guo 2020).

Akoto (2016, pp. 26-27) postulates that there can be the presence of a J-curve effect where "a worsening of the trade balance resulting from a depreciation of a particular currency may be temporary" which implies that the trade balance would tend to be negative after depreciation, but over time the trade balance becomes positive when the elasticities of imports and exports increase. The J-curve phenomenon was observed for countries such as Turkey (Halicioglu 2008), Chile, Ecuador and Uruguay (Hsing 2010), Armenia, Georgia and Ukraine (Nusair 2017), and Cameroon (Dongfack and Ouyang 2019).

A few studies have indicated that the Marshall-Lerner condition holds when examining aggregate trade. Hsing (2010) examines the Marshall-Lerner condition of the bilateral trade between the US and Hong Kong, India, Japan, Korea, Malaysia, Pakistan, Singapore and Thailand. The results indicate that the Marshall-Lerner condition holds for India, Korea, Japan and Pakistan. Another study by Eita (2013) utilizes a cointegrating vector autoregression framework to estimate the impact of change in exchange rate on the trade balance and determine whether the Marshall-Lerner condition holds in Namibia. Findings reveal both imports and exports are significantly impacted by a change in the exchange rate and the Marshall-Lerner condition holds for Namibia.

Caporale et al. (2015) test the Marshall-Lerner condition in Kenya using fractional integration and cointegration methods. Results indicate that cointegration exists between the balance of payments to the real exchange rate and relative income and that the MarshallLerner condition holds in the long run. Therefore, moderate depreciation of the Kenyan currency can stabilize the current account without increasing interest rates. Similarly, Turkay (2014) uses a cointegration approach and an error correction model to determine the validity of the Marshall-Lerner condition in Turkey over the period 1980-2012. Findings supports the validity of the Marshall-Lerner condition in Turkey as the elasticity of export and import demands is higher than 1 in the long run, but no significant relationships existed in the short run. Cambazoglu and Gunes (2016) also find supporting evidence of the Marshall-Lerner condition using an ARDL approach in Turkey in relation to trade with its significant trade partner Germany over the period 2010 to 2014.

A number of studies established that the Marshall-Lerner condition does not hold for aggregate trade. Research by Boyd and Smith (2005) examines how the balance of payments responds to domestic and foreign real incomes and the real exchange rate for 10 Caribbean economies including Jamaica, Guyana and T\&T, the East Caribbean Central Bank (Antigua and Barbuda, Dominica, Grenada, St. Kitts and Nevis and St. Vincent and the Grenadines), Barbados and Belize using Granger Causality, a vector error correction model (VECM) and an autoregressive distributed lag (ARDL) model. The results indicated that the Marshall-Lerner condition does not hold and the J-curve effect does not exist in 
these countries. Findings are similar to Whitehall (1986) who identified that the MarshallLerner condition would have a minimal impact on small countries in the Caribbean, given characteristics such as their small size, market share and export competencies, through an elasticities approach. Richards (1996) utilizes an elasticities approach and absorption approach to determine that the Marshall-Lerner condition does not hold in Jamaica. It is also determined that for Jamaica, devaluation improves exports demand in the very long run and gives rise to a very long J-curve. Richards (1996) noted that in the short run there was a positive reaction of exports to the 1979 and 1983 devaluation which resulted in a two-year lag predicted by the J curve effect. However, imports do not respond to a depreciation as expected, which led to a decline in Jamaica's payment position.

A study by Straughn (2004) uses a VECM and impulse response function to determine that the Marshall-Lerner condition does not hold in T\&T, Barbados and Jamaica using the terms of trade, the real national income, the real money stock and the trade balance equations. Additionally, Wilson and McLean (2014) also use an ARDL model to test the Marshall-Lerner condition in Jamaica, Guyana, T\&T, Barbados and the Dominican Republic. The results indicate that the Marshall-Lerner condition does not hold for Trinidad and Tobago, Barbados and the Dominican Republic and the J-curve effect does not exist in these countries. However, Wilson and McLean noted that the J-curve effect holds and a devaluation would benefit Jamaica and Guyana in the short run only, but the MarshallLerner condition does not hold in the long run.

Shahzad et al. (2017) examined whether the Marshall-Lerner condition would improve the trade balance of South Asian countries, mainly Bangladesh, Bhutan, India, Maldives, Nepal, Pakistan and Sri-Lanka, from 1993 to 2010. This was carried out utilizing pooled ordinary least squares, fixed effects and random effects modelling. The results indicate that the Marshall-Lerner condition does not hold as the sum of export and import elasticities is less than one and depreciation would not improve the trade balance of these countries. Other measures such as export promotion and import substitution industrialization can be considered to improve the trade balance. Another study by Adhikari (2018) indicated that the Marshall-Lerner condition does not hold as the real exchange rate is negative but insignificant and a depreciation of the US dollar does not influence US China trade in the long run and produces a flat J-curve effect.

Behar and Fouejieu (2018) in a recent study, stated that many oil exporters must find ways to improve their external balances after a decline in oil prices. The authors use the OLS fixed effects approach, generalized least squares and GMM system estimator in order to determine the current account response to real exchange rate changes. The results showed that there was little or no relationship with the exchange rate for less diversified oil exporters and a strong relationship with the fiscal balance or government spending. Behar and Fouejieu (2018) stated that government spending has an impact on the current account through imports, exports, investment and remittance income flows. Additionally, the special characteristics of oil exporters make the exchange rate ineffective in improving their external balances. It is noted that a depreciation can lead to some income compression, however, for undiversified oil economies there is limited scope for import substitution and the increased price for imports following the depreciation can weaken the trade balance. Additionally, Behar and Fouejieu (2018) note that oil producers are price-takers producing at full capacity and this can have a minimal impact on exports.

A few studies have examined the Marshall-Lerner condition on industry trade. A study by Nolazco (2012) utilizes a panel of seemingly unrelated regression to determine whether the Marshall-Lerner condition would hold on a sectoral basis for Peru, using unbalanced panel data for the period 1980-2010. The results indicate that the Marshall-Lerner condition holds for the beverages and tobacco and machinery and transport equipment sectors and a depreciation of the currency would have a favorable impact on these sectors. However, it does not apply to other sectors including food and live animals, crude materials, inedibles, except fuels, mineral fuels, lubricants, animal and vegetable oils, fats, chemicals 
and manufactured goods and therefore depreciation is therefore not recommended for these sectors.

On the other hand, Bahmani-Oskooee and Hosny (2013) note that previous research on devaluation and depreciation uses aggregate trade data between one country and the rest of the world or bilateral trade and has provided mixed results leading to aggregation bias. Bahmani-Oskooee and Hosny (2013) note that there can be a loss of information due to aggregation and also different commodity flows between countries can react differently to prices and have different elasticities. Data between Egypt and the EU was disaggregated at commodity level for 59 industries and findings support for the Marshall-Lerner condition holds for 39 industries.

A later study by Arruda et al. (2019) investigated whether the Marshall-Lerner condition and J-curve phenomenon is applicable to improving the trade balance for the Southern region of Brazil, over the period 1999 to 2013 using error correction vectors. The results indicate that the Marshall-Lerner condition holds as there is a positive response of net exports in the south of Brazil to exchange rate devaluation. This also has a positive effect on manufactured goods in Southern regions of Brazil. Arruda et al. (2019) also determined that the J-curve phenomenon does not exist for the Southern region of Brazil's trade balance.

Another recent study by Chebbi and Olarreaga (2019) examined the impact of changes in Tunisia's exchange rate on the net external position of the agricultural sector. Tunisian agricultural trade was found to have a positive long run relationship with the exchange rate which was indicative that the Marshall-Lerner condition did not hold and a continuous depreciation of the Tunisian Dinar is associated with a deterioration of the agricultural trade balance in the long run.

More recently, Guo (2020) used industry-level data from 2008 to 2018 to calculate the export and import price elasticities of demand by using an ARDL model in order to determine whether a devaluation of China's currency will affect the trade balance with the United States where China experiences a trade surplus. The results indicate that the Marshall-Lerner condition does not hold for China and variation of the Chinese exchange rate would not be successful in adjusting the trade balance in the Chinese economy.

Hence, based on the above discussion the following hypotheses are formulated and tested in this paper:

Hypothesis 1 (H1). Devaluing the TT dollar does not have a significant impact on aggregate trade.

Hypothesis 2 (H2). Devaluation of the TT dollar is feasible in promoting non-energy trade and exports.

\section{Data}

For the period 1991 to 2019, the TT dollar has been incrementally depreciating from TTD 4.25 to USD 1 in 1991, to TTD 6.75 to USD 1 in 2019, under a managed float system by the Central Bank of T\&T (see Figure 1). The period 1991 to 2019 was chosen to cover the previous devaluation of the TT dollar in 1993 and 2016. The TT dollar floated in April 1993. The Central Bank of Trinidad and Tobago (2016) noted that there was a depreciation of the TT dollar by 5.4\% in February 2016. Specifically, there have not been major changes to the currency even as the country faces a fall in export revenue inflows. In the same time period the current account balance (CAB) fluctuated from USD $4.66 \mathrm{mn}$ in 1991 (as a result of oil prices falling by 12\% from 1990 to 1991), reaching a peak in 2008 at USD $8499 \mathrm{mn}$ as a result of the natural gas boom and elevated oil and gas prices, then trended downwards to USD $1023.38 \mathrm{mn}$ by 2019. Being a heavy exporter of petroleum products, there is a mirror relationship between T\&T's energy revenues and the current account balance. As it stands, the T\&T economy is at the end of a natural gas boom that started in 1999, and there have only been incremental increases to non-energy exports (manufacturing and agriculture) mainly on account of the Dutch disease. 


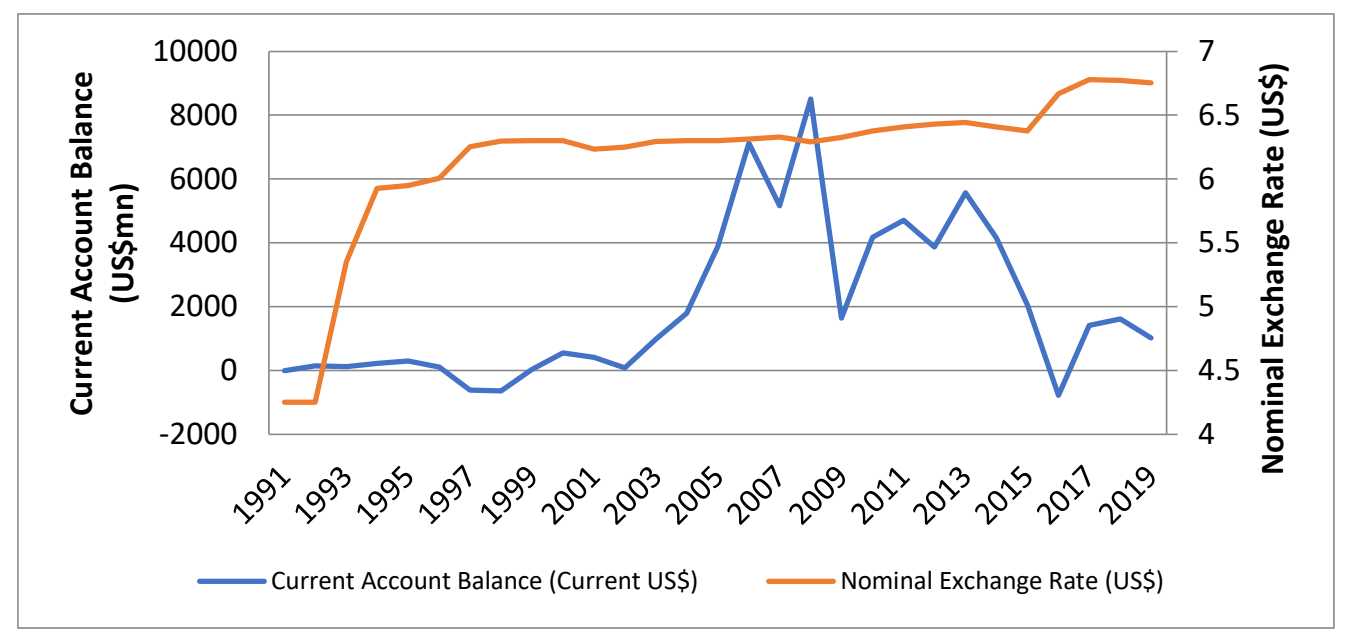

Figure 1. The relationship between the nominal exchange rate and current account balance for T\&T over the period 1991-2019.

Measures are therefore necessary to stimulate non-energy exports in order to cushion the effects of the Dutch disease; Dutch disease occurs when a boom in the booming tradable sector, such as a natural resource discovery, leads to windfall gains that negatively affect the non-booming tradable sector such as agriculture and manufacturing while there is an unsustainable expansion of the services sector. Corden and Neary (1982) specify that the non-booming tradable sector, such as manufacturing, contracts twice; firstly on account of the resource movement effect leading to direct deindustrialization, and secondly via the spending effect due to indirect deindustrialization. The mechanics of the Dutch disease result in an appreciation of the real effective exchange rate as increasing prices in the economy make manufacturing exports less competitive in the external market. This in turn hampers the growth of the non-booming tradable sector.

\section{Data Collection and Variables}

Annual data used for this panel study was collected from the World Bank WDI Indicators, the Central Bank of Trinidad and Tobago and World Integrated Trade Solutions (WITS) for the period 1991-2019. Panel data for sectoral trade for T\&T is only available from WITS until 2015, hence mirror data was used from 2016 to 2019 to get an updated dataset. To further explain this point, although exports were not available from T\&T to a partner country after 2015, export data was obtained from the partner country's imports from T\&T and import data can be obtained using the partner country's exports to T\&T for the period 2016 to 2019.

T\&T's main trading partner countries included in the study comprise Barbados, Canada, Chile, China, the United Kingdom, Guyana, Jamaica, Peru, the United States of America and India. The variables used were: (i) the country's ratio for aggregate trade (LAGTR) - the trade balance is assessed by using the ratio of the value of exports to imports. This ratio of the trade balance method was also used by Bahmani-Oskooee and Alse (1994), Bahmani-Oskooee and Kantipong (2001), Boyd et al. (2001), Wilson and McLean (2014) and Caporale et al. (2015); (ii) the ratio of non-energy trade (LNETR); (iii) the domestic income represented by (GDPD); (iv) the foreign income of the partner countries (GDPF); (v) the nominal exchange rate (LNER); (vi) the money supply (LMS); (vii) and a dummy variable was also included for the period 1999 to 2010 when T\&T experienced a natural gas boom (NGB). Each trade balance ratio model was then disaggregated by investigating the impact of changes to the nominal exchange rate on exports (LAGEX and LNEEX) and imports (LAGIM and LNEIM).

These variables were chosen as a combination based on their use in previous studies on the Caribbean region identified by Whitehall (1986), Richards (1996), Straughn (2004) and Wilson and McLean (2014) and also in terms of their economic relevance. The ratio 
of aggregate bilateral trade was replaced by the ratio of non-energy trade in this paper in order to isolate the dependent variable from energy sector shocks which can result in the $\mathrm{CAB}$ being dominated by energy revenues and a dummy variable was included to capture the effects of the natural gas boom (NGB). Table 1 presents summary statistics of the variables used in this study.

Table 1. Summary statistics of variables under study.

\begin{tabular}{|c|c|c|c|c|c|}
\hline Variable & Obs & Mean & Std. Dev. & Min & Max \\
\hline \multicolumn{6}{|c|}{ Logged variables $(L)$} \\
\hline LAGTR & 290 & 0.577 & 0.482 & 0 & 1.899 \\
\hline$L A G E X$ & 290 & 4.749 & 1.208 & 0 & 6.933 \\
\hline LAGIM & 290 & 4.665 & 0.807 & 2.417 & 6.554 \\
\hline LNETR & 290 & 0.305 & 0.358 & 0 & 1.289 \\
\hline LNEEX & 290 & 3.974 & 1.257 & 0 & 5.945 \\
\hline LNEIM & 290 & 4.548 & 0.815 & 2.330 & 6.402 \\
\hline LNER & 290 & 0.788 & 0.048 & 0.628 & 0.831 \\
\hline$L M S$ & 290 & 6.773 & 0.360 & 6.287 & 7.229 \\
\hline \multicolumn{6}{|c|}{ Unlogged variables } \\
\hline GDPD & 290 & 3.883 & 4.810 & -5.602 & 14.441 \\
\hline GDPF & 290 & 3.738 & 3.487 & -5.693 & 14.231 \\
\hline \multicolumn{6}{|c|}{ Dummy variable } \\
\hline$N G B$ & 290 & 0.414 & 0.493 & 0 & 1 \\
\hline
\end{tabular}

Note: There were countries with zero trade flows for different years under study.

Stationarity testing was carried out using the Levin et al. (2002), and Im et al. (2003) tests for stationarity and presented in Table A1 in the Appendix A. The former test assumes a common unit root process whereas the latter allows the unit root process to vary across cross sections. The variables were found to be $\mathrm{I}(0)$ and $\mathrm{I}(1)$. Hence, a panel ARDL model using a pooled mean group estimator was used to derive results. This approach is used as the above unit root tests reveals a combination of $\mathrm{I}(1)$ and $\mathrm{I}(0)$ variables. Vieira and Silva (2019) note that the ARDL model proposed by Pesaran and Shin (1999) and Pesaran et al. (2001) has an advantage over the cointegration tests in non-stationary variables developed by Engle and Granger (1987), Phillips and Hansen (1990) and Johansen (1991) in traditional VAR models as they are more efficient in capturing cointegration or the long run relationship data in small samples and perform well irrespective of whether variables are stationary I(0), non-stationary I(1), or even mutually cointegrated (Pesaran and Shin 1999).

\section{Empirical Model}

This paper uses a panel ARDL model using a pooled mean group estimator (PMG) to determine whether a depreciation of the TT dollar would have a significant impact on both aggregate and non-energy trade. Erdem et al. (2014) note that the PMG estimator is favored over the mean group (MG) estimator since it is the more efficient and consistent estimator. Models were rerun using dynamic fixed effects. Our study uses the PMG estimator proposed by Pesaran et al. (1999), based on a cointegrated ARDL framework adapted for a panel data set environment. Vieira and Silva (2019) note that the PMG likelihood estimators as proposed by Pesaran et al. (1999) estimate long run coefficients, capture the pooling behavior of homogeneity restrictions and short run coefficients by the average across groups to obtain means of the estimated error-correction coefficients and other short run parameters. The Hausman test suggests the PMG efficient estimator, and is preferred to mean-grouped (MG) estimator.

Our long run model can be written as follows:

$$
Y_{j, i t}=\beta_{0}+\beta_{1 j} L N E R_{i t}+\beta_{2 j} L M S_{i t}+\beta_{3 j} G D P D_{i t}+\beta_{4 j} G D P F_{i t}+\beta_{5 j} N G B_{i t}+\varepsilon_{j, i t}
$$

where $Y_{j, i t}$ denotes the dependent variable $j=1, \ldots$ 6: $\operatorname{LAGTR}(j=1)$ and $\operatorname{LNETR}(j=2)$ are the ratio of the trade balances for aggregate and non-energy trade. $\operatorname{LAGEX}(j=3)$ and 
$\operatorname{LNEEX~}(j=4)$ are aggregate and non-energy (manufacturing representative of SITC 6, 7 and 8 and agriculture representative of SITC 0,1, 2 and 4) exports in US\$000s. LAGIM $(j=5)$ and $\operatorname{LNEIM}(j=6)$ are aggregate and non-energy trade imports in US\$000s]. GDPD is Real GDP growth (\%) in the domestic economy and GDPF is the real GDP growth in the partner country. LNER is the nominal exchange rate (LCU per US\$), LMS (converted to US\$000s) is the money supply and NGB represents the period of a natural gas boom in T\&T where 1 represents years affected by the boom and zero otherwise (see Table 1).

The Marshall-Lerner condition is represented by a positive and significant relationship of the nominal exchange rate variable (Wilson and McLean 2014) in the long run. However, note that a devaluation can worsen the trade balance first and later improve it (which gives rise to the J-curve) where the sign of the exchange rate coefficient determines the J-curve pattern as it moves initially from a negative sign in the short run to a positive sign in the long run. Wilson and McLean (2014) notes that this is linked to the observation that imports are relatively inelastic in the short run and consumers are unable to fully switch their consumption patterns as goods may have been ordered abroad and are still on shipment into the country due to preexisting contracts or because the required goods are not being produced in the requisite quantity at that point in time. Therefore, a country's trade balance may continue to be negative after a devaluation which is indicative of the negative and significant sign of the exchange rate (see Krugman and Obstfeld 2000; Lal and Lowinger 2002; Bahmani-Oskooee and Ratha 2004; Petrovic and Gligoric 2010; Wilson and McLean 2014). However, in the long run, consumer spending becomes more elastic and therefore expenditure switching can be undertaken which aims at reducing imports and increased consumption of local goods (reflective of a positive sign of the variable in the long run).

\section{Empirical Findings}

\subsection{Aggregate Trade}

Our results of the determinants of LAGTR, LAGEX and LAGIM are presented in Table 2. Note that the error correction mechanism (EC) was negative and statistically significant for all models used indicating the presence of cointegration among variables. All models were tested using the Pedroni test, Kao and Westerlund tests and all models indicated cointegration among variables (results are available upon request).

Table 2. The determinants of T\&T's aggregate trade 1991-2019 using PMG estimator.

\begin{tabular}{|c|c|c|c|c|c|c|c|c|}
\hline \multicolumn{3}{|c|}{$\begin{array}{c}\text { Aggregate Trade Balance } \\
\text { Ratio Model (I) }\end{array}$} & \multicolumn{3}{|c|}{$\begin{array}{l}\text { Aggregate Exports } \\
\text { Model (II) }\end{array}$} & \multicolumn{3}{|c|}{$\begin{array}{l}\text { Aggregate Imports } \\
\text { Model (III) }\end{array}$} \\
\hline$L A G T R$ & Coef. & $p$-Value & LAGEX & Coef. & $p$-Value & LAGIM & Coef. & $p$-Value \\
\hline \multicolumn{9}{|c|}{ Long run } \\
\hline LNER & 0.267 & 0.561 & LNER & -0.174 & 0.762 & LNER & -0.162 & 0.734 \\
\hline LMS & 0.154 & $0.011^{* *}$ & LMS & 0.811 & $0.000^{* * *}$ & LMS & 0.504 & $0.000^{* * *}$ \\
\hline GDPD & -0.004 & 0.460 & GDPD & 0.012 & $0.034^{* *}$ & GDPD & 0.016 & $0.000^{* * *}$ \\
\hline GDPF & 0.017 & $0.028^{* *}$ & GDPF & 0.021 & $0.042^{* *}$ & GDPF & 0.012 & 0.188 \\
\hline NGB & 0.190 & $0.000^{* * *}$ & $N G B$ & 0.214 & $0.000^{* * *}$ & $N G B$ & -0.066 & $0.035^{* *}$ \\
\hline \multicolumn{9}{|c|}{ Short run } \\
\hline$E C$ & -0.442 & $0.000^{* * *}$ & $E C$ & -0.530 & $0.000^{* * *}$ & $E C$ & -0.388 & $0.000^{* * *}$ \\
\hline$\triangle L N E R$ & 0.845 & 0.130 & $\triangle L N E R$ & -6.447 & 0.127 & $\triangle L N E R$ & -1.350 & 0.089 * \\
\hline$\Delta L M S$ & -0.639 & 0.263 & $\Delta L M S$ & -3.228 & $0.066^{*}$ & $\Delta L M S$ & 0.632 & $0.053^{*}$ \\
\hline$\triangle G D P D$ & 0.002 & 0.466 & $\triangle G D P D$ & -0.025 & $0.088^{*}$ & $\triangle G D P D$ & -0.003 & 0.159 \\
\hline$\triangle G D P F$ & -0.002 & 0.657 & $\triangle G D P F$ & 0.019 & 0.162 & $\triangle G D P F$ & 0.002 & 0.656 \\
\hline$\Delta N G B$ & -0.094 & $0.000^{* * *}$ & $\Delta N G B$ & -0.136 & 0.334 & $\triangle N G B$ & 0.017 & 0.496 \\
\hline _cons & -0.296 & $0.000^{* * *}$ & _cons & -0.139 & 0.289 & _cons & 0.658 & $0.008^{* * *}$ \\
\hline
\end{tabular}

Notes: ${ }^{*} 10 \%$ level of significance; ${ }^{* *} 5 \%$ level of significance; ${ }^{* * *} 1 \%$ level of significance. Observations: 290.

Model (I) shows that the ML condition does not hold for aggregate trade, Model (II) reveals that aggregate exports are not affected significantly by changes to the LNER and from Model (III), aggregate imports are also not significantly affected by the LNER in the 
long run. Specifically, examining Table 2, the Marshall-Lerner condition does not hold as the LNER coefficient is positive and statistically insignificant in the long run (Model I) for the LAGTR. This is not surprising, as in the long run, the economics literature identifies that the Marshall-Lerner condition does not hold in small Caribbean countries. Whitehall (1986) identified that the Marshall-Lerner condition would have a minimal impact on small countries in the Caribbean given characteristics such as their small size, market share and export competencies through an elasticities approach. Additionally, given that Trinidad and Tobago is a petroleum-exporting economy, the findings support Behar and Fouejieu (2018), who state that there was little or no relationship with the exchange rate for less diversified oil exporters and a strong relationship with the fiscal balance or government spending. Additionally, the special characteristics of oil exporters make the exchange rate ineffective in improving their external balances. A J-curve effect is also absent for LAGTR. We find that there is a positive and statistically significant relationship between $M S$ and GDPF on the LAGTR in the long run. The NGB has a positive and statistically significant effect on the aggregate trade balance ratio as expected in the long run.

The findings, therefore, support Hypothesis 1, as devaluing the TT dollar does not have a significant impact on aggregate trade in the long run. This is consistent with the findings of Boyd and Smith (2005), Straughn (2004) and Wilson and McLean (2014) where the Marshall-Lerner condition does not hold for T\&T concerning aggregate trade. Wilson and McLean (2014) stated that most developing countries are price takers and devaluing the currency increases the competitive gains of producing agents which increases their profits as local cost is fixed in the short run. Once these profits are reinvested, this increases exports and the trade balance in the short run. However, these producing agents face increased cost of inputs which erodes their competitive gains in the long run. This contracts exports and negatively impacts the trade balance. Wilson and McLean (2014) further add that in the short run consumers will respond to the increasing prices by temporarily reducing their consumption of imported items which improves the trade balance in the short run. However, in the long run, this becomes unsustainable since a lack of strong import substitutability will lead to consumers reverting to their original consumption patterns.

From Model (II), LNER does not significantly influence aggregate exports in either the short run or the long run. Hence, devaluing the TT dollar would not have a significant impact on stimulating aggregate exports in either time period. In the long run, $L M S$, GDPD, GDPF and NGB all have positive and statistically significant effects on aggregate exports as expected for a petroleum-exporting country. As it concerns Model (III), there is a negative and significant relationship between the LNER and imports in the short run, showing that devaluing the TT dollar would assist in curbing aggregate imports in this time-period. However, the LNER becomes insignificant in the long run. There is a positive and statistically significant relationship between aggregate imports and GDPD, as expected, which can be indicative of the spending effect of the Dutch disease. Although the NGB does not carry the expected sign effect on aggregate imports, the NGB coefficient is positive and statistically significant in determining aggregate trade as expected.

\subsection{Non-Energy Trade}

Table 3 shows the determinants of LNETR, LNEEX and LNEIM. Similarly, the EC coefficient was negative and statistically significant for all models used, indicating the presence of cointegration among variables. The Pedroni test, Kao test and Westerlund test also suggested cointegration among variables (results are available upon request). 
Table 3. The determinants of T\&T's non-energy trade (manufacturing and agriculture) 1991-2019 using PMG estimator.

\begin{tabular}{|c|c|c|c|c|c|c|c|c|}
\hline \multicolumn{3}{|c|}{ Non-Energy Trade Balance Ratio Model (IV) } & \multicolumn{3}{|c|}{ Non-Energy Exports Model (V) } & \multicolumn{3}{|c|}{ Non-Energy Imports Model (VI) } \\
\hline $\begin{array}{c}\text { Non- } \\
\text { Energy Ratio }\end{array}$ & Coef. & $p$-Value & $\begin{array}{c}\text { Non- } \\
\text { Energy } \\
\text { Exports }\end{array}$ & Coef. & $p$-Value & $\begin{array}{c}\text { Non- } \\
\text { Energy } \\
\text { Imports }\end{array}$ & Coef. & $p$-Value \\
\hline \multicolumn{9}{|c|}{ Long run } \\
\hline LNER & 0.548 & $0.041^{* *}$ & LNER & 3.153 & $0.000^{* * *}$ & LNER & -0.281 & 0.573 \\
\hline$L M S$ & -0.064 & $0.014^{* *}$ & LMS & 0.105 & 0.105 & $L M S$ & 0.473 & $0.000^{* * *}$ \\
\hline GDPD & -0.003 & 0.169 & GDPD & 0.007 & 0.171 & GDPD & 0.018 & $0.000^{* * *}$ \\
\hline GDPF & 0.014 & $0.000^{* * *}$ & GDPF & 0.011 & 0.172 & GDPF & 0.016 & 0.117 \\
\hline$N G B$ & -0.001 & 0.967 & $N G B$ & -0.017 & 0.609 & $N G B$ & -0.070 & $0.041^{* *}$ \\
\hline \multicolumn{9}{|c|}{ Short run } \\
\hline$E C$ & -0.411 & $0.000^{* * *}$ & $E C$ & -0.431 & $0.000^{* * *}$ & $E C$ & -0.368 & $0.000^{* * *}$ \\
\hline$\triangle L N E R$ & -0.130 & 0.553 & $\triangle L N E R$ & -3.695 & 0.139 & $\triangle L N E R$ & -1.506 & $0.043^{* *}$ \\
\hline$\Delta L M S$ & -0.210 & 0.101 & $\triangle L M S$ & -0.624 & 0.437 & $\Delta L M S$ & 0.613 & $0.021^{* *}$ \\
\hline$\triangle G D P D$ & 0.000 & 0.718 & $\triangle G D P D$ & -0.014 & $0.051^{*}$ & $\triangle G D P D$ & -0.006 & $0.001^{* * *}$ \\
\hline$\triangle G D P F$ & -0.003 & 0.200 & $\triangle G D P F$ & 0.020 & 0.357 & $\triangle G D P F$ & 0.003 & 0.494 \\
\hline$\Delta N G B$ & -0.039 & 0.218 & $\Delta N G B$ & -0.126 & 0.216 & $\Delta N G B$ & -0.006 & 0.767 \\
\hline _cons & 0.101 & $0.011^{* *}$ & _cons & 0.302 & 0.248 & _cons & 0.683 & $0.007^{* * *}$ \\
\hline
\end{tabular}

Notes: ${ }^{*} 10 \%$ level of significance; ${ }^{* *} 5 \%$ level of significance; ${ }^{* * *} 1 \%$ level of significance. Observations: 290.

Model (IV) shows that the ML condition holds for non-energy trade, Model (V) reveals that non-energy exports are affected significantly by changes to the LNER, hence a devaluation would make non-energy exports cheaper which in turn stimulates exports, and from Model (VI), LNER is statistically insignificant in determining LNEIM in the long run. In particular, for Model (IV), the LNER coefficient is negative and statistically insignificant in the short run, but positive and statistically significant in the long run. Therefore, the nonenergy trade balance would be significantly affected in the long run following a depreciation of the exchange rate as the non-energy balance would eventually improve. This shows that the Marshall-Lerner condition would hold for non-energy trade in the long run. This is not surprising, as over the period 1999 to 2019 , the TT dollar has depreciated $58.93 \%$ increasing from USD 4.25 in 1991 to USD 6.75 by 2019. Although there has been a decline in non-energy exports over the period 2012 to 2019; non-energy exports (manufacturing and agriculture) generally increased by $250.49 \%$ from 1991 to 2019. Isolating the effects of energy revenues, therefore, gives a better understanding of the exchange rate effectiveness on non-energy exports. The small, twin-island state is at the tail end of its natural gas boom and is in need of alternatives to diversify its economy: non-energy exports provide an avenue to do so. In the long run, the LNER does not have a significant impact on the aggregate trade ratio as expected, therefore a devaluation of the TT dollar would not significantly affect aggregate exports in the long run. However, isolating non-energy trade provides a means to significantly promote non-energy exports whilst not having a significant impact on aggregate exports. Arruda et al. (2019) noted that an exchange rate devaluation in Brazil, where the Marshall-Lerner condition held, had a positive and elastic effect on net exports and this was more pronounced for manufactured goods.

GDPF has a positive and significant impact on non-energy trade in the long run. LMS has a negative and significant impact on non-energy trade in the long run, probably as an increase in the LMS leads to an increase in spending on foreign goods and at the same time leads to a decrease in production of non-energy export goods in favor of services as a result of Dutch disease.

As it concerns Model $(\mathrm{V})$, there is a positive and significant impact between the LNER and LNEEX which indicates that devaluing the TT dollar would stimulate non-energy exports in the long run. This finding supports Hypothesis 2 that devaluing the TT currency can promote non-energy exports in a small petroleum-exporting economy experiencing Dutch disease. 
Model (VI) reveals that the $L N E R$ has a negative and statistically significant impact in reducing $L N E I M$, in the short run, however, this becomes positive and insignificant in the long run; revealing that non-energy imports are inelastic in the long run and would not significantly be affected by devaluation of the TT dollar. This is indicative that, in the short run, consumers will respond to the increasing prices by temporarily reducing their consumption of imported items which improves the trade balance in the short run. However, in the long run this becomes unsustainable since a lack of strong import substitutability will lead to consumers reverting to their original consumption patterns. Similarly, the NGB does not carry the expected sign of non-energy imports as it was negative and statistically significant. However, we are of the view that the spending effect associated with the NGB can be partly explained via the positive and significant impact of GDPD on non-energy imports as expected. Note that the NGB coefficient is insignificant in determining non-energy trade.

\subsection{Alternative Specification}

We also used a dynamic fixed effects regression (DFE) estimator which serves as a further robustness check to determine whether the ML condition holds for aggregate and non-energy trade in T\&T (see Tables A2 and A3 in the Appendix A); this estimator restricts not only the cointegrating vector to be equal across panels, but also the short run coefficients and the speed of adjustment coefficients (Pesaran et al. 1999). We also allow for intragroup correlation in the calculation of standard errors. Findings from aggregate trade using the PMG estimator are consistent with findings from the DFE estimator whereby a devaluation of the TT currency would stimulate trade and curb aggregate imports in the short run, however, the Marshall-Lerner condition does not hold in the long run and devaluing the currency does not have a statistically significant effect on aggregate trade (supports Hypothesis 1). However, the findings from non-energy trade using the PMG estimator are also similar to the findings from the DFE estimator. The LNER is positive and statistically significant for the DFE estimator and the Marshall-Lerner condition holds in the long run: that is, devaluing the currency does have a statistically significant effect on non-energy trade (supports Hypothesis 2).

\subsection{What Measures Can Be Implemented along with a Devaluation of the Currency to Stimulate} Non-Energy Trade in TET?

The Marshall-Lerner condition stipulates that a devaluation of a country's currency would lead to a positive and significant relationship between the LNER and the trade balance in the long run. Based on the findings from Models I to VI, the Marshall-Lerner condition holds for non-energy trade. However, to increase the likelihood that a devaluation, if undertaken, will work, other measures should be considered to promote non-energy exports.

Three important additional measures in promoting non-energy exports and dampening the effect of Dutch disease include assessing the potential for import substitution, improving the ease of doing business environment and an examination of current and potential market assessment. Our analysis suggests that other measures should be implemented to complement devaluation of the currency to promote non-energy exports.

\subsubsection{Is There Potential for Import Substitution?}

This paper uses the methodology used by Moore et al. (2015) to determine whether there is a potential for import substitution in T\&T. Data were collected from the International Trade Centre and also UNCOMTRADE for T\&T and are presented in Table 4. For T\&T in 2019, 21.71\% of the country's import bill can be import substituted but this includes minerals, oils and distillation products. However, by excluding minerals, oils and distillation products, T\&T can only import substitute $6.81 \%$ of its import bill. The other four goods that are heavily imported cannot be perfectly substituted in order to fulfill local demand. Table A4 in the Appendix A shows that for the period 2004 to 2019, in general, there was limited scope for import substitution for T\&T, especially post 2012. A point to 
note is that a large portion of the potential for import substitution for T\&T is due to the fact that the country can completely import substitute petroleum products. For the other highly imported products such as machinery, vehicles, electronics and ore, slag and ash, there is limited potential for import substitution. T\&T is a small state with a narrow production base and the decrease in output from the manufacturing and agricultural sectors is also contributing to an increased demand for imports of final and intermediate goods.

Table 4. Potential for import substitution industrialization for T\&T for 2019.

\begin{tabular}{|c|c|c|c|c|}
\hline $\begin{array}{l}\text { Top Five Imported } \\
\text { Commodities }\end{array}$ & $\begin{array}{l}\text { Import Value } \\
\text { (USD 000s) }\end{array}$ & $\begin{array}{l}\text { \% of Total } \\
\text { Imports }\end{array}$ & $\begin{array}{l}\text { Export Value } \\
\text { (USD 000s) }\end{array}$ & $\begin{array}{c}\text { Max Import } \\
\text { Substitution } \\
\text { Value }{ }^{\wedge} \\
\text { (USD 000s) }\end{array}$ \\
\hline $\begin{array}{l}\text { Machinery, mechanical } \\
\text { appliances, boilers ... } \\
\text { parts thereof }\end{array}$ & $1,194,861$ & 17.13 & 340,181 & 340,181 \\
\hline $\begin{array}{l}\text { Mineral fuels, mineral oils } \\
\text { and products of their } \\
\text { distillation; bituminous } \\
\text { substances; mineral ... }\end{array}$ & $1,115,367$ & 15.99 & $5,658,571$ & $1,115,367$ \\
\hline $\begin{array}{l}\text { Vehicles other than } \\
\text { railway or tramway } \\
\text { rolling stock, and parts } \\
\text { and accessories thereof }\end{array}$ & 404,326 & 5.80 & 7414 & 7414 \\
\hline $\begin{array}{l}\text { Electrical machinery and } \\
\text { equipment and parts } \\
\text { thereof; sound recorders } \\
\text { and reproducers, } \\
\text { televisions ... }\end{array}$ & 356,202 & 5.11 & 38,035 & 38,035 \\
\hline Ores, slag and ash & 353,123 & 5.06 & 13,114 & 13,114 \\
\hline Total imports & $6,974,900$ & 49.09 & & $1,514,111$ \\
\hline \multicolumn{4}{|c|}{ Potential for import substitution industrialization } & $\%$ \\
\hline \multicolumn{4}{|c|}{ Max import substitutes as a \% of total imports with minerals } & 21.71 \\
\hline \multicolumn{4}{|c|}{ Max import substitutes as a $\%$ of total imports without minerals } & 6.81 \\
\hline
\end{tabular}

Notes: “ This indicates the corresponding amount of exports that were exported from the home country under the top categories in which they were imported. "Moore et al. (2015, p. 22) indicates that the maximum potential for import substitution of these categories is determined by a country's export production, up to a maximum of total imports of the category given that the country is "an efficient exporter and is also producing and exporting to its maximum potential, at the ruling international price, to an infinitely large market".

\subsubsection{Improving the Ease of Doing Business in T\&T}

Over the period 2014 to 2019, T\&T has seen a decline in seven of the ten areas of doing business; two areas have improved whilst one area remained unchanged. Devaluation of the T\&T currency may also occur in tandem with improving the ease of doing business in the country. Table A5 in Appendix A shows the EODB rankings and measures in which the T\&T economy can benefit in order to improve non-energy exports from T\&T to other developing countries especially in areas for starting a business, dealing with construction permits, getting electricity, getting credit, protecting minority investors, paying taxes and improving trading across borders. We recommend that T\&T examine these or similar changes to improve their EODB ranking on a pillar by pillar basis.

\subsubsection{Assessing Current and Potential Markets}

In order to assess whether export growth can be targeted to current and potential markets, a TradeCAN/RCA analysis can be used. Using RCA would give the areas in which the country has a "revealed" comparative advantage based on its exports; specifically, $\mathrm{RCA}_{\mathrm{ij}}=\frac{X_{i j} / X_{i t}}{X_{w j} / X_{w t}}$, where $X_{i j}$ and $X_{w j}$ are country $i$ 's exports of product $j$ and world exports of product $j$ and $X_{i t}$ and $X_{w t}$ are country $i$ 's total exports and world exports respectively. 
Combining the results from a TradeCAN analysis, dynamic (increasing demand and market share) areas in the international import market and the domestic export market can be identified and this can help to give an improved subset of export commodities, by which resources can be streamlined or towards which revenues can be channeled to propel the growth of the non-energy sector in the country. Specifically, TradeCAN was created via a cooperative venture of the United Nations Economic Commission for Latin America and the Caribbean (UNECLAC) and can be used to understand the market positioning for the country and reveal areas changes to market share and market structure. The paper manually calculates the formulas in the TradeCAN methodology, as the original TradeCAN is a statistical software package, the data for which stopped in 2012, that derives various permutations of ways that a country is placed for growth in the world market. There are four possibilities in a TradeCAN analysis. A rising star reflects export areas that are dynamic products and which are gaining market share. A missed opportunity is reflective of areas that have lost market share in dynamic products. Declining stars are reflective of areas that are gaining market share in stagnant export areas. Retreat areas reflect decreasing market share for stagnant export areas. Therefore, countries should focus on dynamic areas that are considered rising stars and missed opportunities.

Government incentives can boost export growth in these dynamic areas which are positioned to have increasing demand together with a revealed comparative advantage for T\&T (see Tables A6 and A7 in Appendix A).

\section{Conclusions}

Testing the Marshall-Lerner condition for aggregate trade using a panel ARDL approach shows that devaluation does not hold for aggregate trade, with no apparent J-curve effect. However, a devaluation of the TT dollar would have a positive and significant impact on both non-energy exports and non-energy trade in the long run and the Marshall-Lerner condition therefore holds for non-energy trade.

The results from the aggregate model show that the ML condition does not hold for aggregate trade, exports are not affected significantly by changes to the nominal exchange rate and imports are inelastic in the long run. In the short run, aggregate imports respond negatively and significantly to changes in the nominal exchange rate, showing that devaluing the TT dollar would assist in curbing aggregate imports in this time period. However, the nominal exchange rate becomes insignificant in the long run, which shows that T\&T has a small size and supply capacity, imports are inelastic in the long run, and both consumers and firms would have to resort to increasing imports for non-import substitutable commodities, raw materials and intermediate goods in the long run. As it concerns nonenergy trade, the ML condition holds for non-energy trade and non-energy exports can be stimulated by devaluation of the nominal exchange rate. However, non-energy imports are inelastic in the long run, likely due to T\&T's limited production base for non-energy goods.

Other measures other than a devaluation of the TT dollar would be necessary to promote non-energy trade, specifically manufacturing trade, in the long run. The findings reveal that there is limited scope for import substitution in T\&T, especially post 2012. T\&T is a small state with a narrow production base and the decrease in output from the manufacturing and agricultural sectors is partially contributing to increased demand for imports of final and intermediate goods sourced from the international market. Therefore, from a policy perspective, emphasis must be placed by policy makers on improving the ease of doing business in the country, especially in areas for starting a business, dealing with construction permits, getting electricity, getting credit, protecting minority investors, paying taxes and improving trading across borders in order to boost economic activity in the manufacturing and agriculture sectors. Policy makers in T\&T should also reconsider current and prospective markets to promote areas that are in demand internationally which include rising stars and missed opportunities, but also areas in which T\&T simultaneously has a revealed comparative advantage in order to promote non-energy exports. 
Author Contributions: Investigation, R.H. and L.B.; methodology, L.B. and G.S.; data collection, L.B.; formal analysis, R.H. and L.B.; supervision, R.H. and G.S. project administration, R.H. and G.S.; writing—original draft, R.H. and L.B.; writing—review and editing, R.H., L.B. and G.S. All authors have read and agreed to the published version of the manuscript.

Funding: This research received no external funding.

Institutional Review Board Statement: Not applicable.

Informed Consent Statement: Not applicable.

Data Availability Statement: Data for this study was accessed from the World Development Indicators, World Integrated Trade Solutions and Central Bank of Trinidad and Tobago.

Conflicts of Interest: The authors declare no conflict of interest.

\section{Appendix A}

Table A1. Unit root test results.

\begin{tabular}{|c|c|c|c|c|c|c|}
\hline Variable & \multicolumn{3}{|c|}{ Levin, Lin and Chu (LLC) } & \multicolumn{3}{|c|}{ Im, Pesaran and Shin (IPS) } \\
\hline & Level & $\begin{array}{c}\text { 1st } \\
\text { Difference }\end{array}$ & $\begin{array}{l}\text { Order of } \\
\text { Variable }\end{array}$ & Level & $\begin{array}{c}\text { 1st } \\
\text { Difference }\end{array}$ & $\begin{array}{l}\text { Order of } \\
\text { Variable }\end{array}$ \\
\hline LAGTR & $\begin{array}{c}0.7073 \\
(0.7603) \\
\end{array}$ & $\begin{array}{c}-4.4551 \\
(0.0000)^{* * *}\end{array}$ & $\mathrm{I}(1)$ & $\begin{array}{c}-1.4605 \\
(0.0721) *\end{array}$ & & $\mathrm{I}(0)$ \\
\hline LNETR & $\begin{array}{c}-2.5726 \\
(0.0050)^{* * *}\end{array}$ & & $\mathrm{I}(0)$ & $\begin{array}{c}-4.1949 \\
(0.0000)^{* * *}\end{array}$ & & $\mathrm{I}(0)$ \\
\hline$L A G E X$ & $\begin{array}{l}-1.0328 \\
(0.1509)\end{array}$ & $\begin{array}{c}-6.1059 \\
(0.0000)^{* * *}\end{array}$ & $\mathrm{I}(1)$ & $\begin{array}{c}-2.2854 \\
(0.0111)^{* *}\end{array}$ & & $\mathrm{I}(0)$ \\
\hline LAGIM & $\begin{array}{c}-2.5831 \\
(0.0049)^{* *}\end{array}$ & & $\mathrm{I}(0)$ & $\begin{array}{c}-2.7691 \\
(0.0028)^{* * *}\end{array}$ & & $\mathrm{I}(0)$ \\
\hline LNEEX & $\begin{array}{c}-4.2239 \\
(0.0000)^{* * *}\end{array}$ & & $\mathrm{I}(0)$ & $\begin{array}{c}-3.1097 \\
(0.0009) * *\end{array}$ & & $\mathrm{I}(0)$ \\
\hline LNEIM & $\begin{array}{c}-2.5759 \\
(0.0050)^{* *}\end{array}$ & & $\mathrm{I}(0)$ & $\begin{array}{c}-3.2667 \\
(0.0005) * * *\end{array}$ & & $\mathrm{I}(0)$ \\
\hline LNER & $\begin{array}{c}-35.5429 \\
(0.0000)^{* * *}\end{array}$ & & $\mathrm{I}(0)$ & $\begin{array}{c}-8.1769 \\
(0.0000) * * *\end{array}$ & & $\mathrm{I}(0)$ \\
\hline LMS & $\begin{array}{l}-0.6392 \\
(0.2614)\end{array}$ & $\begin{array}{c}-5.5264 \\
(0.0000)^{* * *}\end{array}$ & $\mathrm{I}(1)$ & $\begin{array}{c}5.2510 \\
(1.0000)\end{array}$ & $\begin{array}{c}-5.4482 \\
(0.0000)^{* * *}\end{array}$ & $\mathrm{I}(1)$ \\
\hline GDPD & $\begin{array}{l}-0.6278 \\
(0.2651) \\
\end{array}$ & $\begin{array}{c}-8.2015 \\
(0.0000)^{* * *}\end{array}$ & $\mathrm{I}(1)$ & $\begin{array}{c}-4.2770 \\
(0.0000) * * *\end{array}$ & & $\mathrm{I}(0)$ \\
\hline GDPF & $\begin{array}{c}-4.3661 \\
(0.0000)^{* * *}\end{array}$ & & $\mathrm{I}(0)$ & $\begin{array}{c}-5.9940 \\
(0.0000) * * *\end{array}$ & & $\mathrm{I}(0)$ \\
\hline NGB & $\begin{array}{c}0.1989 \\
(0.5788)\end{array}$ & $\begin{array}{c}-6.4334 \\
(0.0000)^{* * *}\end{array}$ & $\mathrm{I}(1)$ & $\begin{array}{c}0.1312 \\
(0.5522)\end{array}$ & $\begin{array}{c}-6.4550 \\
(0.0000)^{* * *}\end{array}$ & $\mathrm{I}(1)$ \\
\hline
\end{tabular}

Note: $* * *$ Statistically significant at $1 \%$ level, ${ }^{* *}$ statistically significant at $5 \%$ level, ${ }^{*}$ statistically significant at $10 \%$ level. The number in brackets ( ) indicates $p$-values. 
Table A2. The determinants of T\&T's aggregate trade 1991-2019 using DFE.

\begin{tabular}{|c|c|c|c|c|c|c|c|c|}
\hline \multicolumn{3}{|c|}{$\begin{array}{c}\text { Aggregate Trade Balance Ratio } \\
\text { Model (I) }\end{array}$} & \multicolumn{3}{|c|}{$\begin{array}{l}\text { Aggregate Exports } \\
\text { Model (II) }\end{array}$} & \multicolumn{3}{|c|}{$\begin{array}{l}\text { Aggregate Imports } \\
\text { Model (III) }\end{array}$} \\
\hline LAGTR & Coef. & $p$-Value & LAGEX & Coef. & $p$-Value & LAGIM & Coef. & $p$-Value \\
\hline \multicolumn{9}{|c|}{ Long run } \\
\hline LNER & 2.235 & 0.299 & LNER & 1.282 & 0.676 & LNER & -0.501 & 0.811 \\
\hline LMS & 0.259 & 0.255 & $L M S$ & 1.071 & $0.016^{* *}$ & $L M S$ & 0.795 & $0.001^{* * *}$ \\
\hline GDPD & -0.017 & 0.431 & GDPD & -0.022 & 0.529 & GDPD & 0.026 & $0.020^{* *}$ \\
\hline GDPF & 0.041 & 0.224 & GDPF & 0.031 & 0.379 & GDPF & -0.016 & 0.524 \\
\hline$N G B$ & 0.214 & 0.224 & NGB & 0.320 & $0.084^{*}$ & $N G B$ & -0.049 & 0.502 \\
\hline \multicolumn{9}{|c|}{ Short run } \\
\hline$E C$ & -0.232 & $0.000^{* * *}$ & $E C$ & -0.380 & $0.000^{* * *}$ & $E C$ & -0.300 & $0.002^{* * *}$ \\
\hline$\triangle L N E R$ & 1.279 & 0.103 & $\triangle L N E R$ & -4.595 & 0.130 & $\triangle L N E R$ & -0.832 & 0.224 \\
\hline$\Delta L M S$ & -0.555 & $0.057^{*}$ & $\Delta L M S$ & -2.789 & 0.102 & $\Delta L M S$ & 0.529 & 0.154 \\
\hline$\triangle G D P D$ & 0.005 & 0.163 & $\triangle G D P D$ & -0.010 & 0.410 & $\triangle G D P D$ & -0.002 & 0.430 \\
\hline$\triangle G D P F$ & -0.002 & 0.535 & $\triangle G D P F$ & 0.026 & 0.127 & $\triangle G D P F$ & 0.010 & $0.090^{*}$ \\
\hline$\triangle N G B$ & -0.042 & $0.011^{* *}$ & $\triangle N G B$ & -0.046 & 0.723 & $\Delta N G B$ & 0.000 & 0.998 \\
\hline _cons & -0.715 & $0.028^{* *}$ & _cons & -1.254 & 0.273 & _cons & -0.086 & 0.878 \\
\hline
\end{tabular}

Notes: ${ }^{*} 10 \%$ level of significance; $* * 5 \%$ level of significance; ${ }^{* * *} 1 \%$ level of significance. Observations: 290.

Table A3. The determinants of T\&T's non-energy trade 1991-2019 using DFE.

\begin{tabular}{|c|c|c|c|c|c|c|c|c|}
\hline \multicolumn{3}{|c|}{ Non-Energy Trade Balance Ratio Model (IV) } & \multicolumn{3}{|c|}{ Non-Energy Exports Model (V) } & \multicolumn{3}{|c|}{ Non-Energy Imports Model (VI) } \\
\hline $\begin{array}{c}\text { Non-Energy } \\
\text { Ratio }\end{array}$ & Coef. & $p$-Value & $\begin{array}{c}\text { Non- } \\
\text { Energy } \\
\text { Exports }\end{array}$ & Coef. & $p$-Value & $\begin{array}{c}\text { Non- } \\
\text { Energy } \\
\text { Imports }\end{array}$ & Coef. & $p$-Value \\
\hline \multicolumn{9}{|c|}{ Long run } \\
\hline LNER & 1.288 & $0.025^{* *}$ & LNER & 7.655 & 0.092 * & LNER & -0.743 & 0.710 \\
\hline$L M S$ & -0.098 & 0.220 & $L M S$ & 0.197 & 0.605 & LMS & 0.689 & $0.002^{* *}$ \\
\hline GDPD & -0.000 & 0.980 & GDPD & 0.020 & 0.331 & GDPD & 0.027 & $0.051^{*}$ \\
\hline GDPF & 0.020 & 0.080 * & GDPF & 0.077 & $0.014^{* *}$ & GDPF & -0.026 & 0.362 \\
\hline$N G B$ & 0.015 & 0.647 & $N G B$ & 0.196 & 0.508 & $N G B$ & -0.082 & 0.327 \\
\hline \multicolumn{9}{|c|}{ Short run } \\
\hline$E C$ & -0.458 & $0.000^{* * *}$ & $E C$ & -0.443 & $0.000^{* * *}$ & $E C$ & -0.305 & $0.002^{* * *}$ \\
\hline$\triangle L N E R$ & -0.317 & 0.514 & $\triangle L N E R$ & -0.913 & 0.639 & $\triangle L N E R$ & -1.041 & $0.042^{* *}$ \\
\hline$\Delta L M S$ & -0.356 & $0.072^{*}$ & $\Delta L M S$ & -1.466 & 0.310 & $\Delta L M S$ & 0.513 & 0.178 \\
\hline$\triangle G D P D$ & -0.001 & 0.384 & $\triangle G D P D$ & -0.013 & 0.163 & $\triangle G D P D$ & -0.004 & $0.070^{*}$ \\
\hline$\triangle G D P F$ & -0.004 & 0.277 & $\triangle G D P F$ & 0.014 & 0.476 & $\triangle G D P F$ & 0.013 & 0.059 * \\
\hline$\triangle N G B$ & -0.055 & 0.149 & $\Delta N G B$ & -0.246 & $0.047^{* *}$ & $\triangle N G B$ & -0.014 & 0.498 \\
\hline _cons & -0.045 & 0.883 & _cons & -1.652 & 0.238 & _cons & 0.168 & 0.772 \\
\hline
\end{tabular}

Notes: ${ }^{*} 10 \%$ level of significance; ${ }^{* *} 5 \%$ level of significance; ${ }^{* * *} 1 \%$ level of significance. Observations: 290.

Table A4. Trends in potential for import substitution in T\&T 2005-2019.

\begin{tabular}{|c|c|c|c|c|c|c|c|c|}
\hline Country & $\mathbf{2 0 0 4}$ & $\mathbf{2 0 0 6}$ & $\mathbf{2 0 0 8}$ & $\mathbf{2 0 1 0}$ & $\mathbf{2 0 1 2}$ & $\mathbf{2 0 1 5}$ & $\mathbf{2 0 1 7}$ & $\mathbf{2 0 1 9}$ \\
\hline Trinidad and Tobago (\%) & 26.38 & 37.44 & 43.00 & 30.58 & 51.76 & 33.98 & 20.79 & 21.71 \\
\hline $\begin{array}{c}\text { Trinidad and Tobago } \\
\text { without minerals (\%) }\end{array}$ & 3.93 & 4.30 & 9.15 & 13.19 & 17.57 & 7.96 & 4.94 & 6.81 \\
\hline
\end{tabular}


Table A5. Measures that can be adopted to improve the EODB pillars in T\&T.

\begin{tabular}{|c|c|c|c|c|}
\hline \multicolumn{4}{|c|}{$\begin{array}{c}\text { Ease of Doing Business (EODB) Ranking } \\
\text { for T\&T 2014-2020 }\end{array}$} & \multirow[t]{2}{*}{$\begin{array}{l}\text { Suggestions to Improve EODB } \\
\text { Rankings as Performed by Other } \\
\text { Caribbean Countries and SIDS }\end{array}$} \\
\hline TT EODB Ranking & 2014 & 2020 & & \\
\hline Global Rank & 66 & 105 & Worsened & \\
\hline Starting a Business & 67 & 76 & Decline & $\begin{array}{l}\text {-Make starting a business faster by } \\
\text { improving the exchange of information } \\
\text { between public entities involved in } \\
\text { company incorporation (Antigua and } \\
\text { Barbuda, Doing Business 2020, } \\
\text { World Bank 2020). } \\
\text { - Make starting a business faster by } \\
\text { reducing the registration time for the } \\
\text { business license and value added tax } \\
\text { and by eliminating the business } \\
\text { registration fee (The Bahamas, Doing } \\
\text { Business 2020, World Bank 2020). } \\
\text { - Make starting a business easier by } \\
\text { reducing the minimum capital } \\
\text { requirement (Dominican Republic, } \\
\text { Doing Business 2020, } \\
\text { World Bank 2020). }\end{array}$ \\
\hline $\begin{array}{l}\text { Dealing with } \\
\text { Construction } \\
\text { Permits }\end{array}$ & 77 & 125 & Decline & $\begin{array}{l}\text {-Make dealing with construction } \\
\text { permits easier by enhancing its } \\
\text { risk-based approach to inspections, } \\
\text { improving public access to soil } \\
\text { information, and streamlining the } \\
\text { process to obtain a construction permit } \\
\text { (Singapore, Doing Business 2020, } \\
\text { World Bank 2020). } \\
\text {-Make dealing with construction } \\
\text { permits faster by streamlining internal } \\
\text { processes (The Seychelles, Doing } \\
\text { Business 2020, World Bank 2020). }\end{array}$ \\
\hline Getting Electricity & 10 & 41 & Decline & $\begin{array}{l}\text {-Make getting electricity more } \\
\text { transparent by publishing electricity } \\
\text { tariffs online (The Bahamas, Doing } \\
\text { Business 2020, World Bank 2020). } \\
\text {-Make getting electricity faster by } \\
\text { deploying new software to process } \\
\text { applications, increasing the stock of } \\
\text { material needed for external } \\
\text { connection works, and offering } \\
\text { training programs to the utility's } \\
\text { engineers (Barbados, Doing Business } \\
\text { 2020, World Bank 2020). } \\
\text {-Belize made getting electricity faster } \\
\text { by offering training to its utility field } \\
\text { engineers and upgrading its } \\
\text { geographic information system to map } \\
\text { the electricity distribution network } \\
\text { (Belize, Doing Business 2020, } \\
\text { World Bank 2020). }\end{array}$ \\
\hline Getting Credit & 28 & 60 & Decline & $\begin{array}{l}\text {-Improve access to credit information } \\
\text { through the introduction of regulations } \\
\text { that govern the licensing and } \\
\text { functioning of credit bureaus (St. Kitts } \\
\text { and Nevis, Doing Business 2020, } \\
\text { World Bank 2020). }\end{array}$ \\
\hline
\end{tabular}


Table A5. Cont.

\begin{tabular}{|c|c|c|c|c|}
\hline \multicolumn{4}{|c|}{$\begin{array}{l}\text { Ease of Doing Business (EODB) Ranking } \\
\text { for T\&T 2014-2020 }\end{array}$} & \multirow{2}{*}{$\begin{array}{l}\text { Suggestions to Improve EODB } \\
\text { Rankings as Performed by Other } \\
\text { Caribbean Countries and SIDS } \\
\text { - Strengthen minority investor } \\
\text { protections by increasing disclosure } \\
\text { requirements for conflicts of interest, } \\
\text { clarifying ownership and control } \\
\text { structures, and requiring greater } \\
\text { corporate transparency (The Bahamas, } \\
\text { Doing Business 2020, } \\
\text { World Bank 2020). }\end{array}$} \\
\hline $\begin{array}{c}\text { Protecting } \\
\text { Minority Investors }\end{array}$ & 22 & 57 & Decline & \\
\hline Paying Taxes & 97 & 166 & Decline & $\begin{array}{l}\text {-Make paying taxes easier by } \\
\text { enhancing the online valueadded tax } \\
\text { reporting system and making it more } \\
\text { accessible to taxpayers (The Bahamas, } \\
\text { Doing Business 2020, World Bank 2020). } \\
\text { - Make paying taxes less costly by } \\
\text { reducing the corporate income tax rate } \\
\text { (St. Vincent and the Grenadines, Doing } \\
\text { Business 2020, World Bank 2020). }\end{array}$ \\
\hline $\begin{array}{l}\text { Trading across } \\
\text { Borders }\end{array}$ & 73 & 130 & Decline & $\begin{array}{l}\text {-Make trading across borders easier } \\
\text { by streamlining inspections by port } \\
\text { authorities and introducing an } \\
\text { electronic system for documentary } \\
\text { compliance (Barbados, Doing } \\
\text { Business 2020, World Bank 2020). }\end{array}$ \\
\hline Enforcing Contracts & 174 & 174 & No change & $\begin{array}{l}\text {-Make enforcing contracts easier by } \\
\text { adopting a law that regulates all } \\
\text { aspects of mediation as an alternative } \\
\text { dispute resolution mechanism } \\
\text { (Barbados, Doing Business 2020, } \\
\text { World Bank 2020). } \\
\text { - Make enforcing contracts easier by } \\
\text { introducing a judicial performance } \\
\text { measurement mechanism that } \\
\text { provides publicly available } \\
\text { information on time to disposition and } \\
\text { clearance rate (Jamaica, Doing } \\
\text { Business 2020, World Bank 2020). }\end{array}$ \\
\hline
\end{tabular}


Table A6. Examples of feasible export areas for T\&T's main extra-regional markets.

\begin{tabular}{|c|c|c|c|c|c|}
\hline \multicolumn{6}{|c|}{ US Market } \\
\hline SITC R3 & RCA Index & $\begin{array}{c}\text { Missed } \\
\text { Opportunities }\end{array}$ & SITC R3 & RCA Index & Rising Stars \\
\hline 91 & 1.498 & $\begin{array}{c}\text { Margarine } \\
\text { and shortening }\end{array}$ & 278 & 13.191 & $\begin{array}{l}\text { Other crude } \\
\text { minerals. }\end{array}$ \\
\hline 334 & 3.889 & $\begin{array}{l}\text { Petroleum oils or } \\
\text { bituminous } \\
\text { minerals } \\
>70 \% \text { oil }\end{array}$ & 282 & 1.475 & $\begin{array}{c}\text { Ferrous waste, } \\
\text { scrap; remelting } \\
\text { ingots, iron, steel. }\end{array}$ \\
\hline 522 & 127.838 & $\begin{array}{c}\text { Inorganic } \\
\text { chemical } \\
\text { elements, oxides } \\
\text { and halogen salts }\end{array}$ & 289 & 3.047 & $\begin{array}{c}\text { Ores and } \\
\text { concentrates of } \\
\text { precious metals; } \\
\text { waste, scrap. }\end{array}$ \\
\hline & & & 562 & 22.390 & $\begin{array}{l}\text { Fertilizers (other } \\
\text { than those of } \\
\text { group 272) }\end{array}$ \\
\hline & & & 671 & 34.753 & $\begin{array}{l}\text { Pig iron and } \\
\text { spiegeleisen, sponge } \\
\text { iron, powder } \\
\text { and granu. }\end{array}$ \\
\hline \multicolumn{6}{|c|}{ EU market } \\
\hline \multirow[t]{5}{*}{676} & 4.625 & $\begin{array}{l}\text { Iron and steel } \\
\text { bars, rods, } \\
\text { angles, shapes } \\
\text { and sections }\end{array}$ & 342 & 4.560 & $\begin{array}{l}\text { Liquefied propane } \\
\text { and butane. }\end{array}$ \\
\hline & & & 343 & 33.288 & $\begin{array}{l}\text { Natural gas, } \\
\text { whether or } \\
\text { not liquefied. }\end{array}$ \\
\hline & & & 512 & 96.9435 & $\begin{array}{c}\text { Alcohols, phenols, } \\
\text { halogenat. } \\
\text { sulfonat., nitrat. der. }\end{array}$ \\
\hline & & & 522 & 8.7611 & $\begin{array}{l}\text { Inorganic chemical } \\
\text { elements, oxides } \\
\text { and halogen salts. }\end{array}$ \\
\hline & & & 562 & 4.5489 & $\begin{array}{l}\text { Fertilizers (other } \\
\text { than those of } \\
\text { group 272). }\end{array}$ \\
\hline
\end{tabular}

Source: World Integrated Trade Solutions, author calculations. 
Table A7. Examples of feasible export areas for T\&T's main intra-regional markets.

\begin{tabular}{|c|c|c|c|c|c|}
\hline \multicolumn{6}{|c|}{ Guyana market } \\
\hline SITC R3 & RCA Index & $\begin{array}{c}\text { Missed } \\
\text { Opportunities }\end{array}$ & SITC R3 & RCA Index & Rising Stars \\
\hline 17 & 1.949 & $\begin{array}{c}\text { Meat, edible } \\
\text { meat offal, } \\
\text { prepared, } \\
\text { preserved, n.e.s. }\end{array}$ & 98 & 1.061 & $\begin{array}{l}\text { Edible products and } \\
\text { preparations, n.e.s. }\end{array}$ \\
\hline 278 & 1.209 & $\begin{array}{l}\text { Other crude } \\
\text { minerals. }\end{array}$ & & & \\
\hline 642 & 1.916 & $\begin{array}{c}\text { Paper and } \\
\text { paperboard, cut } \\
\text { to shape or } \\
\text { size, articles. }\end{array}$ & & & \\
\hline 661 & 1.422 & $\begin{array}{l}\text { Lime, cement, } \\
\text { fabrica. constr. } \\
\text { mat. (excluding } \\
\text { glass, clay). }\end{array}$ & & & \\
\hline 665 & 1.178 & Glassware & & & \\
\hline 676 & 1.633 & $\begin{array}{l}\text { Iron and steel } \\
\text { bars, rods, } \\
\text { angles, shapes } \\
\text { and sections. }\end{array}$ & & & \\
\hline \multicolumn{6}{|c|}{ Jamaica market } \\
\hline \multirow[t]{3}{*}{48} & 5.228 & $\begin{array}{c}\text { Cereal } \\
\text { preparations, } \\
\text { flour of fruits } \\
\text { or vegetables }\end{array}$ & 122 & 10.161 & $\begin{array}{l}\text { Tobacco, } \\
\text { manufactured }\end{array}$ \\
\hline & & & 533 & 1.120 & $\begin{array}{l}\text { Pigments, paints, } \\
\text { varnishes and } \\
\text { related materials. }\end{array}$ \\
\hline & & & 581 & 2.823 & $\begin{array}{l}\text { Tubes, pipes and } \\
\text { hoses of plastics. }\end{array}$ \\
\hline \multicolumn{6}{|c|}{ Dominican Republic market } \\
\hline 111 & 1.197 & $\begin{array}{c}\text { Non-alcoholic } \\
\text { beverages, n.e.s. }\end{array}$ & 893 & 1.177 & $\begin{array}{c}\text { Articles, n.e.s., } \\
\text { of plastics. }\end{array}$ \\
\hline
\end{tabular}

Source: World Integrated Trade Solutions, author calculations.

\section{References}

Adhikari, Deergha Raj. 2018. Testing the Marshall-Lerner Condition and the J-Curve Effect on U.S-China Trade. Journal of Applied Business and Economics 20: 11-18. [CrossRef]

Akoto, Linda. 2016. An Empirical Analysis of the Determinants of Trade Balance in Post-Liberalisation Ghana. Master of Philosophy thesis, Kwame Nkrumah University of Science and Technology, Kumasi, Ghana.

Arruda, Elano, Pablo Urano De Carvalho Castelar, and Gabriel Martins. 2019. The J-Curve and the Marshall-Lerner condition: Evidence from net exports in the Southern Region of Brazil. Journal of Planning and Public Policies 52: 17-48.

Bahmani, Mohsen, Hanafiah Harvey, and Scott W. Hegerty. 2013. Empirical Tests of the Marshall-Lerner Condition: A Literature Review. Journal of Economic Studies 40: 411-43. [CrossRef]

Bahmani-Oskooee, Mohsen, and Janardhanan Alse. 1994. Short-run versus long-run effects of devaluation: error correction modeling and cointegration. Eastern Economic Journal 20: 453-64.

Bahmani-Oskooee, Mohsen, and Amr Sadek Hosny. 2013. Long-Run Price Elasticities and the Marshall-Lerner Condition: Evidence from Egypt-EU Commodity Trade. The European Journal of Development Research 25: 695-713. [CrossRef]

Bahmani-Oskooee, Mohsen, and Tachawan Kantipong. 2001. Bilateral J-Curve Between Thailand and Her Trading Partners. Journal of Economic Development 26: 107-117.

Bahmani-Oskooee, Mohsen, and Artatrana Ratha. 2004. The J-Curve Dynamics of U.S. Bilateral Trade. Journal of Economics and Finance 28: 32-38. [CrossRef]

Behar, Alberto, and Armand Fouejieu. 2018. External Adjustment in Oil Exporters: The Role of Fiscal Policy and the Exchange Rate. The World Economy 41: 926-57. [CrossRef]

Boyd, Derick, and Ron Smith. 2005. The Marshall-Lerner Condition and the J-Curve Effect: Balance of Payments Adjustment in the Caribbean. Caribbean Dialogue 10: 31-46. 
Boyd, Derick, Gugielmo Maria Caporale, and Ron Smith. 2001. Real Exchange Rate Effects on the Balance of Trade: Cointegration and the Marshall-Lerner Condition. International Journal of Finance E Economics 6: 197-200. [CrossRef]

Cambazoglu, Birgul, and Sevcan Gunes. 2016. Marshall-Lerner Condition Analysis: Turkey Case. Economics, Management, and Financial Markets 11: 272-83.

Caporale, Guglielmo Maria, Robert Mudida, and Luis Alberiko Gil-Alana. 2015. Testing the Marshall-Lerner Condition in Kenya. South African Journal of Economics 83: 253-68. [CrossRef]

Central Bank of Trinidad and Tobago. 2016. 2016 Annual Economic Survey. Port of Spain: Central Bank of Trinidad of Tobago.

Chebbi, Houssem Eddine, and Marcelo Olarreaga. 2019. Investigating Exchange Rate Shocks on Agricultural Trade Balance: The Case of Tunisia. The Journal of International Trade E Economic Development 28: 628-47. [CrossRef]

Corden, W. Max, and J. Peter Neary. 1982. Booming Sector and De-Industrialisation in a Small Open Economy. The Economic Journal 92: 825-48. [CrossRef]

Dongfack, Laetitia P. Sokeng, and Hongbing Ouyang. 2019. The Impact of Real Exchange Rate Depreciation on Cameroon's Trade Balance: Is Devaluation a Remedy for Persistent Trade Deficits? Journal of Economic Integration 34: 189-213. [CrossRef]

Eita, Joel Hinaunye. 2013. Estimation of The Marshall-Lerner Condition for Namibia. International Business E Economics Research Journal (IBER) 12: 510-18. [CrossRef]

Engle, Robert, and C. W. Granger. 1987. Co-Integration and Error Correction: Representation, Estimation and Testing. Econometrica 55: 251-76. [CrossRef]

Erdem, Ekrem, Gulbahar Ucler, and Umit Bulut. 2014. Impact of Domestic Credits on the Current Account Balance: A Panel ARDL Analysis for 15 OECD Countries. Actual Problems of Economics 15: 408-16.

Guo, Geato. 2020. Estimating the Marshall-Lerner Condition of China. Journal of Economics and International Finance 12: 48-56.

Halicioglu, Ferda. 2008. The J-curve dynamics of Turkey: an application of ARDL model. Applied Economics 40: 2439-29. [CrossRef]

Hsing, Yu. 2010. Test of the Marshall-Lerner Condition for Eight Selected Asian Countries and Policy Implications. Global Economic Review 39: 91-98. [CrossRef]

Im, Kyung So, Hashem Pesaran, and Yongcheol Shin. 2003. Testing for unit roots in heterogeneous panels. Journal of Econometrics 115: 53-74. [CrossRef]

International Monetary Fund. 2016. Trinidad and Tobago 2016 Article IV Consultation-Press Release and Staff Report. IMF Country Report No. 16/204. Washington, DC: International Monetary Fund.

International Monetary Fund. 2018. Trinidad and Tobago 2018 Article IV Consultation-Press Release and Staff Report. IMF Country Report No. 18/285. Washington, DC: International Monetary Fund.

Johansen, Søren. 1991. Estimation and Hypothesis Testing of Cointegration Vectors in Gaussian Vector Autoregressive Models. Econometrica 59: 1551-80. [CrossRef]

Krugman, Paul, and Maurice Obstfeld. 2000. International Economics, 5th ed. Reading: Addison-Wesley.

Lal, Anil K., and Thomas C. Lowinger. 2002. The J-Curve: Evidence from East Asia. Journal of Economic Integration 17: $397-415$. [CrossRef]

Levin, Andrew, Chien-Fu Chin, and Chia-Shang James Chu. 2002. Unit root tests in panel data: asymptotic and finite-sample properties. Journal of Econometrics 108: 1-24. [CrossRef]

Moore, Winston, Jamila Beckles, and DeLisle Worrell. 2015. Size Structure and Devaluation. Wanstead: The University of the West Indies, Cave Hill Campus Barbados.

Nolazco, Jose. 2012. Re-Examination of the Marshall-Lerner Condition in Peru at a Disaggregated Level: An Analysis in the Unbalanced Panel. SSRN. [CrossRef]

Nusair, Salah. 2017. The J-Curve phenomenon in European transition economies: A nonlinear ARDL approach. International Review of Applied Economics 31: 1-26. [CrossRef]

Pesaran, M. Hashem, and Yongcheol Shin. 1999. An autoregressive distributed lag modeling approach to cointegration analysis. In Econometrics and Economic Theory in 20th Century: the Ragnar Frisch Centennial Symposium. Edited by S. Strom. Cambridge: Cambridge University Press.

Pesaran, M. Hashem, Yongcheol Shin, and Ron P. Smith. 1999. Pooled Mean Group Estimation of Dynamic Heterogeneous Panels. Journal of the American Statistical Association 94: 621-34. [CrossRef]

Pesaran, M. Hashem, Yongcheol Shin, and Ron P. Smith. 2001. Bound testing approaches to the analysis of level relationship. Journal of Applied Economics 16: 289-326. [CrossRef]

Petrovic, Pavle, and Mirjana Gligoric. 2010. Exchange Rate and Trade Balance: J-Curve Effect. Panoeconomicus 1: 23-41. [CrossRef]

Phillips, Peter, and Bruce Hansen. 1990. Statistical Inference in Instrumental Variables Regression with I(1) process. Review of Economic Studies 87: 99-123. [CrossRef]

Regis, Kyron. 2020. Economists: Devaluing TT Dollar Not the Best Option. Trinidad and Tobago Guardian, December 24.

Richards, Dawn. 1996. The Trade Adjustment Debate and Its Implications for Caribbean Economies: The Case of Jamaica, $1962-1991$. ProQuest Dissertations and Theses, UMI Microform, Ann Arbor, MI, USA.

Shahzad, Adnan, Bilal Nafees, and Nazar Farid. 2017. Marshall-Lerner Condition for South Asia: A Panel Study Analysis. Pakistan Journal of Commerce and Social Sciences 11: 559-75.

Straughn, Ryan. 2004. Estimating Long Run Relationships between the Trade Balance and the Terms of Trade in Selected CARICOM Countries. Working Paper 2003-6. Bridgetown: Central Bank of Barbados, pp. 67-86. 
Turkay, Hakan. 2014. The Validity of Marshall-Lerner Condition in Turkey: A Cointegration Approach. Theoretical and Applied Economics XXI 10: 21-32.

Usui, Norio. 1997. Dutch Disease and Policy Adjustments to the Oil Boom. Kokusai Keizai 48: 136-37. [CrossRef]

Vieira, Flavio, and Cleomar Gomes Da Silva. 2019. The Role of International Reserves on Real Exchange Rate: A Panel ARDL Model. Approach. ANPEC 2019: 1-16.

Whitehall, Peter. 1986. Devaluation and Export Earnings in Small Economies: The Marshall-Lerner Insight. Bridgetown: Central Bank of Barbados, pp. 132-35.

Wilson, Shelly-Ann, and Esmond McLean. 2014. Understanding the impact of Exchange Rate Adjustment on the Trade Balance of Selected Caribbean Countries. Working Paper. Kingston: Bank of Jamaica, p. 134.

World Bank. 2020. Doing Business 2020. Washington, DC: World Bank. 